\title{
PENINGKATAN HASIL BELAJAR SISWA DENGAN METODE PENDEKATAN BERBASIS AKTIFITAS PADA MATERI ARUS, TEGANGAN DAN TAHANAN LISTRIK DI SMK NEGERI 1 WONOASRI
}

\author{
Prabakti Endramawan ${ }^{1}$, Yoyok teguh Prasetyo ${ }^{2}$ \\ ${ }^{1}$ Prodi Pendidikan Teknik Elektro, FPTK, IKIP PGRI Madiun \\ Madiun, 63118, Indonesia \\ ${ }^{2}$ Prodi Pendidikan Teknik Elektro, FPTK, IKIP PGRI Madiun \\ Madiun, 63118, Indonesia \\ Email : prabakti67@ikippgrimadiun.ac.id; teguhyoyok87@gmail.com
}

\begin{abstract}
ABSTRAK
Rendahnya keaktifan dan prestasi belajar siswa dalam mata pelajaran Dasar-dasar Elektronika merupakan masalah yang sering muncul dalam pembelajaran Dasar-dasar Elektronika. Hal ini dikarenakan metode pembelajaran yang digunakan guru kurang masih belum mampu membantu siswa dalam meningkatkan keaktifan dan prestasi belajarnya. Pembelajaran melalui metode pembelajaran CTL dapat membuat siswa lebih aktif dan kreatif dalam kegiatan belajar.Penelitian ini bertujuan untuk mengetahui hasil peningkatan keaktifan dan prestasi belajar dasar-dasar elektronika dengan menggunakan metode CTL (Contextual Teaching and Learning). Subyek dari penelitian ini adalah siswa kelas VIII yang berjumlah 28 siswa terdiri dari 12 anak laki-laki dan 16 anak perempuan Pengumpulan data dilakukan dengan menggunakan tes formatif ,Tes dilaksanakan pada akhir siklus. Hasil penelitian menunjukkan bahwa pada keaktifan siklus I 15,82, kemudian pada siklus II 20,78, dan pada tes formatif siklus I 75,35, kemudian pada siklus II 83,92.Berdasarkan hasil penelitian yang telah dilakukan melalui metode CTL (Contextual Teaching and Learning), disimpulkan bahwa metode CTL dapat meningkatkan keaktifan dan prestasi belajar siswa kelas VIII SMP PGRI Karangjati Ngawi
\end{abstract}

Kata Kunci: Metode CTL, Keaktifan Belajar, Prestasi Belajar

\section{Pendahuluan}

Terwujudnya kondisi pembelajaran siswa aktif merupakan harapan dari semua komponen pendidikan termasuk masyarakat dan praktisi pendidikan. Oleh sebab itu dalam kegiatan pembelajaran dituntut suatu strategi pembelajaran yang direncanakan oleh guru dengan mengedepankan keaktifan siswa dalam kegiatan belajar mengajar. Melalui kegiatan belajar yang menekankan pada aktivitas siswa diharapkan mampu meningkatkan motivasi dan hasil belajar yang sesuai dengan tujuan pendidikan di sekolah.
James O Whittaker (Syaiful Bahri Djamarah: 2002) merumuskan belajar sebagai proses dimana tingkah laku ditimbulkan atau diubah melalui latihan atau pengalaman. Begitu pula dengan Slameto juga merumuskan pengertian belajar. Menurutnya belajar adalah suatu proses usaha yang dilakukan individu untuk memperoleh suatu perubahan tingkah laku yang baru secara keseluruhan.

Dengan demikian belajar memiliki arti dasar adanya aktivitas atas kegiatan dan penguasaan tentang sesuatu. Dengan demikian proses siswa aktif dalam 
kegiatan belajar mengajar merupakan suatu kegiatan pembelajaran yang harus dilaksanakan secara terus menerus dan tiada henti. Hal ini dapat dilakukan apabila interaksi antara guru dan siswa terjalin dengan baik. Sebab menurut GagneWinkel (Syaiful Bahri Djamarah: 2002) proses belajar, terutama belajar yang terjadi di sekolah, melalui beberapa tahap atau fase: motivasi, konsentrasi, mengolah, menggali prestasi dan umpan balik/timbal balik antara guru dan siswa.

Berdasarkan pada pendapat tersebut, menunjukkan bahwa aktifitas siswa dalam kegiatan belajar mengajar mutlak diperlukan. Namun yang lebih penting lagi dalam meningkatkan aktifitas siswa tersebut adalah kemampuan guru dalam merencanakan suatu kegiatan belajar mengajar tersebut dalam mencapai tujuan pembelajaran.

Berdasarkan fenomena tersebut, peneliti akan melakukan suatu kegiatan penelitian tindakan pada siswa Kelas X.AV.2Sekolah Menengah Kejuruan Negeri 1 Wonoasri Kabupaten Madiun pada peningkatan motivasi belajar siswa melalui kegiatan pembelajaran berbasis aktivitas. Mengapa harus pembelajaran berbasis aktivitas?

Beberapa alasan peneliti menggunakan pendekatan pengajaran berbasis aktivitas dalam mengajarkan materi pembelajaran Produktif Teknik Audio Video diantaranya:

1. Asas aktivitas digunakan dalam semua jenis metode mengajar baik di dalam maupun diluar kelas.

2. Asas aktivitas bertujuan mengembangkan ide-ide atau merealisasikan

suatu ide dalam suatu bentuk tertentu.

3. Memperoleh pengalaman dan ketrampilan tertentu.

Sedangkan alasan peneliti memilih mata pelajaran Produktif Teknik Audio Video digunakan sebagai materi bahan pendekatan berbasis aktivitas, karena dalam kurikulum Produktif Teknik Audio Video dapat membantu siswa untuk

1. Menjalani kehidupan sehari-hari secara efektif.

2. Memanfaatkan kesempatan untuk mengembangkan kemampuan

berfikir kreatif,fleksibel, dan inovatif.

3. Mengembangkan pengertian tentang konsep-konsep Arus, tegangan, dan Tahanan listrik Teknik Audio Video.

4. Menyiapkan diri untuk studi pada tingkatan yang lebih lanjut.

Dari beberapa alasan pengambilan permasalahan dalam penelitian tindakan kelas tersebut, maka dapat dirumuskan judul penelitian tindakan kelas "Peningkatan Hasil Belajar Siswa dengan Metode Pendekatan Berbasis Aktifitas pada Materi Arus, Tegangan dan Tahanan Listrik di SMK Negeri 1 Wonoari"

Berdasarkan pada latar belakang masalah tersebut di atas, maka dalam penelitian tindakan kelas ini, dapat dirumuskan suatu permasalahan sebagai berikut:

1. Apakahpendekatan berbasis aktivitas lebih efektif dalam menumbuhkan motivasi belajar mata pelajaran Produktif Teknik Audio Video Materi Pembelajaran Arus, Tegangan dan Tahanan Listrik pada siswa Kelas X.AV2 ?

2. Apakah kegiatan belajar mengajar yang menggunakan pendekatan berbasis aktivitas dapatmeningkatkan prestasi belajar siswa Kelas X.AV2. pada mata pelajaran Produktif Teknik Audio Video Materi Pembelajaran Arus, Tegangan dan Tahanan Listrik?

\section{Metode Penelitian}

Penelitian ini tergolong dalam penelitian tindakan kelas Menurut Mills (Wiyono, 2008:1) penelitian tindakan kelas adalah penelitian sistematis yang dilakukan oleh peneliti guru, kepala 
sekolah atau lainnya tentang situasi belajar mengajar di kelas dengan mengumpulkan informasi tentang praktik - praktik kegiatan sekolah, kegiatan mengajar guru, atau kegiatan belajar siswa dalam rangka untuk memperoleh wawasan, mengembangkan praktik-praktik secara reflektif, serta membawa dampak perubahan positif terhadap sekolah, dan meningkatkan hasil belajar siswa.

Untuk memperoleh data yang sesuai dengan tujuan penelitian maka penelitian tindakan kelas ini akan dilaksanakan dalam dua siklus. Masingmasing terdiri dari empat tahapan yaitu perencanaan, pelaksanaan tindakan, pengamatan (observasi), dan refleksi. Adapun alur dari penelitian tindakan kelas ini adalah sebagai berikut :

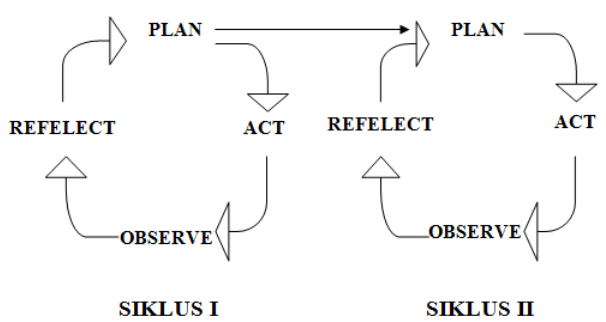

Gambar 1.1 Alur Penelitian Tindakan Kelas.

Langkah-langkah penelitian tindakan kelas adalah sebagai berikut :

1. Perencanaan

Dalam tahap ini peneliti merencanakan langkah-langkah tindakan yang akan dilakukan dalam proses penelitian. Adapun langkahlangkah nya sebagai berikut:

a. Merencanakan langkah-langkah proses tindakan yang akan dilakukan.

b. Mempersiapkan fasilitas dan sarana pendukung yang diperlukan dalam melaksanakan tindakan . c. Mempersiapkan cara melakukan observasi terhadap pelaksanaan tindakan.

d. Membuat skenario apa yang akan dilakukan dalam melaksanakan tindakan.

2. Pelaksanaan tindakan

Kegiatan yang dilaksanakan dalam tahap ini adalah melaksanakan tindakan sesuai dengan rencana yang ditetapkan dalam perencanaan.

3. Observasi

Dalam tahap ini kegiatan utama yang dilakukan adalah mengadakan pengamatan terhadap pelaksanaan tindakan. Fungsi utama observasi adalah untuk mengetahui kesesuaian pelaksanaan tindakan dengan rencana, dan untuk mengetahui seberapa pelaksanaan tindakan yang sedang berlangsung dan harapannya akan memperoleh hasil yang diharapkan.

4. Refleksi

Pada tahap ini data yang diperoleh melalui observasi dikumpulkan dan dianalisis. Melalui refleksi tersebut dapat diketahui keberhasilan dan kekurangan yang dilakukan, sehingga bisa digunakan untuk memperbaiki dan menetapkan tindakan selanjutnya.

Di dalam langkah pengambilan data ini peneliti akan membagi menjadi 2 siklus. Adapun langkah langkah siklus tersebut dapat di uraikan di bawah ini:

\section{Siklus 1}

Didalam siklus 1 ini peneliti belum menggunakan metode pembelajaran sesuai yang di rencanakan. Adapun aktivitas nya sebagai berikut:

\section{Perencanaan/planing.}

Perencanaan pada siklus 1ini membuat perencanaan tentang pembelajaran secara menyeluruh yaitu Peneliti mempersiapkan materi pelajaran yang akan diajarkan dalam pelaksanaan 
tindakan, menyiapkan perangkat pembelajaran diantaranya silabus sesuai dengan kurikulum yang berlaku, Rencana Pelaksanaan Pembelajaran (RPP) dengan metode pembelajaran tradisional dan menyusun soal untuk evaluasi siswa (tes formatif) pada akhir siklus.

2. Pelaksanaan/Akting. pelaksanaan yang di lakukan adalah melaksanakan rencana pembelajaran sesuai dengan rencana pada perencanaan, adapun langkah - langkah sebagai berikut

a. Kegiatan awal yaitu peneliti memberikan pengertian masalah tujuan pembelajaran.

b. Kegiatan inti yaitu peneliti menyampaikan kepada siswa tentang materi pembahasan yaitu menjelaskan pengertian dan prinsip kerja Arus Tegangan danTahanan Listrik, dengan menggunakan metode pembelajaran secara tradisional.

c. Penutup atau kegiatan akhir yaitu peneliti memberikan tes evaluasi pada siswa.

3. Observasi/Observasing.

Mengamati proses belajar dengan menggunakan metode tradisional.

4. Refleksi / refleksing.

Memberi tanggapan atas proses pembelajaran siswa dengan menggunakan metode tradisional. Serta memberikan penilaian terhadap hasil tes.

\section{Siklus 2}

Didalam siklus 2 ini peneliti sudah menggunakan metode pendekatan berbasis aktivitas, adapun aktivitas nya sebagai berikut :
1. Perencanaan/planing.

Perencanaan pada siklus 2 ini peneliti membuat perencanaan seperti perencanaan pada siklus 1, pada siklus ini peneliti sudah menggunakan metode pendekatan berbasis aktivitas.

2. Pelaksanaan/Akting. pelaksanaan yang di lakukan adalah melaksanakan rencana pembelajaran sesuai dengan rencana pada perencanaan, adapun langkah-langkah sebagai berikut :

a. Kegiatan awal yaitu peneliti memberikan pengertian masalah tujuan pembelajaran.

b. Kegiatan inti yaitu peneliti menyampaikan kepada siswa tentang materi pembahasan yaitu menjelaskan pengertian dan prinsip kerja Arus Tegangan danTahanan Listrik. melalui motivasi dengan dilanjutkan aktivitas praktik langsung dengan menggunakan bahan dan alat yang berhubungan dengan arus, tegangan, dan tahanan listrik.

c. Kegiatan akhir atau penutup yaitu peneliti memberikan tes evaluasi pada siswa.

3. Observasi/observasing.

Mengamati proses belajar dengan menggunakan metode berbasis aktivitas yang telah di lakukan siswa.

4. Refleksi/refleksing.

Memberi tanggapan atas proses pembelajaran siswa dengan menggunakan metode berbasis aktivitas. Serta 
memberikan penilaian

terhadap hasil tes.

\section{Hasil Penelitian}

Hasil penelitian ini diperoleh dari kegiatan pengamatan dan observasipeneliti selama kegiatan penelitian berlangsung. Catatan-catatan prestasi tersebut diwujudkan dalam bentuk hasil evaluasi yang dilakukan pada akhir kegiatan setiap siklus.Adapun langkah-langkahnya adalah sebagai berikut:

\section{Siklus 1}

Pada siklus ini rencana tindakan dilakukan dengan alokasi waktu 4 x 45 . Dan belum menggunakan metode pendekatan berbasis aktivitas/masih menggunakan metode tradisional. Hal ini untuk mengetahui seberapa jauh prestasi siswa dan untuk pengambilan data awal. Adapun langkah-langkah pada siklus 1 sebagai berikut:

1. Perencanaan/planing.

Pada langkah ini peneliti membuat perencanaan tentang pembelajaran secara menyeluruh yaitu Peneliti mempersiapkan materi pelajaran yang akan diajarkan dalam pelaksanaan tindakan, menyiapkan perangkat pembelajaran diantaranya silabus sesuai dengan kurikulum yang berlaku, Rencana Pelaksanaan Pembelajaran (RPP) dengan metode pembelajaran tradisional dan menyusun soal untuk evaluasi siswa (tes formatif) pada akhir siklus.

2. Pelaksanaan/Akting.

pelaksanaan yang di lakukan adalah melaksanakan rencana pembelajaran sesuai dengan rencana pada perencanaan, adapun langkahlangkah sebagai berikut:

a. Kegiatan awal yaitu peneliti memberikan pengertian masalah tujuan pembelajaran.Apresiasi berisi penjelasan singkat tentang materi yang akan di bahas b. Kegiatan inti yaitu peneliti menyampaikan kepada siswa tentang materi pembahasan yaitu menjelaskan pengertian dan prinsip kerja Arus Tegangan danTahanan Listrik, dengan menggunakan metode pembelajaran secara tradisional. Setelah peneliti menjelaskan siswa diberi kesempatan untuk bertanya tentang kesulitan yang di hadapi dalam menerima penyampaian materi, dan peneliti akan menjelaskan lagi kesulitan penyampaian materi yang muncul dalam pembelajaran, secara singkat.

c. Penutup atau kegiatan akhir yaitu peneliti memberikan tes evaluasi pada siswa.

3. Observasi/observasing.

Setelah kegiatan belajar mengajar dalam serangkaian kegiatan penelitian dilaksanakan sebelum menggunakan metode pendekatan berbasis aktivitas, selanjutnya peneliti akan memaparkan hasil kegiatan pembelajaran siswa Kelas X.AV2 SMKN 1 Wonoasri Kabupaten Madiun, berkaitan dengan upaya peningkatan motivasi belajar siswa dengan strategi pembelajaran berbasis aktivitas. Adapun secara rinci akan dipaparkan dari hasil observasi dan catatan peneliti tentang hasil belajar, dan prestasi belajar siswa Kelas X.AV2 SMKN 1 Wonoasri Kabupaten Madiun

4. Refleksi/refleksing.

Dari frekuensi data tersebut dapat diketahui bahwa siswa yang mencapai kriteria ketuntasan minimum sebanyak 9 siswa, dan siswa yang mendapatkan diatas kriteria ketuntasan minimum adalah sebanyak 12 siswa, dan yang tidak tuntas 15 siswa. 
Selanjutnya untuk membuktikan keefektifan penggunaan pembelajaran berbasis aktivitas dalam kegiatan belajar mengajar, peneliti akan menggunakan pembelajaran dengan menggunakan metode berbasis aktivitas pada kegiatan siklus 2 ini.

\section{Siklus 2}

Pada siklus ini rencana tindakan dilakukan dengan alokasi waktu 4 x 45 . Dan peneliti sudah menggunakan metode peningkatan prestasi belajar dengan metode pendekatan berbasis aktivitas . Adapun langkah - langkah pada siklus 2 sebagai berikut :

1. Perencanaan/planing.

Pada langkah ini peneliti membuat perencanaan tentang pembelajaran yaitu Peneliti mempersiapkan materi pelajaran yang akan diajarkan dalam pelaksanaan tindakan, menyiapkan perangkat pembelajaran diantaranya silabus sesuai dengan kurikulum yang berlaku, Rencana Pelaksanaan Pembelajaran (RPP) menggunakan metode peningkatan prestasi belajar dengan metode pendekatan berbasis aktivitas, dan perangkat lain sebagai pendukung dalam pembelajaran ini serta menyusun soal untuk evaluasi siswa (tes formatif) pada akhir siklus.

2. Pelaksanaan/Akting.

pelaksanaan yang di lakukan adalah melaksanakan rencana pembelajaran sesuai dengan rencana pada perencanaan, adapun langkah langkah nya adalah sebagai berikut :

a. Kegiatan awal yaitu peneliti memberikan pengertian masalah tujuan pembelajaran. Apresiasi berisi penjelasan singkat tentang materi yang akan di bahas.

b. Kegiatan inti yaitu peneliti menyampaikan kepada siswa tentang materi pembahasan, menjelaskan pengertian dan prinsip kerja Arus Tegangan
danTahanan Listrik, dengan menggunakan metode pendekatan berbasis aktivitas. Setelah peneliti menjelaskan siswa diberi kesempatan untuk bertanya tentang kesulitan yang di hadapi dalam penyampaian materi, dan peneliti akan menjelaskan lagi kesulitan penyampaian materi secara singkat, lalu memberi motivasi tentang materi bahasan sambil menunjukkan alat praktek yang nanti akan digunakan untuk praktek materi pelajaran Arus Tegangan dan Tahan Listrik, setelah itu siswa diperkenankan untuk beraktivitas dengan menggunakan alat praktek sesuai materi bahasan. Setelah selesai kembali seperti semula untuk menjelaskan kepada guru hasil aktivitas yang telah dilakukan sesuai materi bahasan.

c. Penutup atau kegiatan akhir yaitu peneliti memberikan tes evaluasi pada siswa.

3. Observasi/observasing.

Setelah kegiatan belajar mengajar dalam serangkaian kegiatan penelitian dilaksanakan dengan menggunakan metode pendekatan berbasis aktivitas, selanjutnya peneliti akan memaparkan hasil kegiatan pembelajaran siswa Kelas X.AV2 SMKN 1 Wonoasri Kabupaten Madiun, berkaitan dengan upaya peningkatan motivasi belajar siswa dengan strategi pembelajaran berbasis aktivitas. Adapun secara rinci akan dipaparkan dari hasil observasi dan catatan peneliti tentang hasil belajar, dan prestasi belajar siswa Kelas X.AV2 SMKN 1 Wonoasri Kabupaten

Berdasarkan pada kegiatan siklus 2 tersebut, peneliti melakukan refleksi dari hasil kegiatan penelitian sebagai berikut: 
1. Terlihat ada peningkatan motivasi siswa dalam mengikuti kegiatan belajar mengajar dibandingkan dengan kegiatan belajar mengajar sebelumnya (menggunakan strategi tradisional).

2. Beberapa siswa cepat dalam mempelajari materi yang disampaikan oleh guru.

3. Beberapa siswa sudah ada keberanian dalam menyampaikan pendapat.

Berdasarkan data pengamatan dan obeservasi peneliti selama kegiatan penelitian, siswa dalam kegiatan belajar dengan pendekatan berbasis aktivitas menunjukkan ada peningkatan dibandingkan dengan strategi sebelumnya. Hal ini dapat dilihat dari data yang didapatkan oleh peneliti, dan hasil belajar siswa dalam kegiatan belajar mengajar menunjukkan mulai meningkat.

Berdasarkan rekapitulasi hasil evaluasi, siswa dalam mengikuti kegiatan belajar tersebut menunjukkan prestasi belajar siswa semakin meningkat dengan strategi pembelajaran berbasis aktivitas. Sebab dengan pembelajaran berbasis aktivitas, semua siswa dapat melakukan aktivitas dalam kegiatan belajar secara penuh dalam upaya meningkatkan tujuan pembelajaran yang optimal.

\section{Kesimpulan}

Berdasarkan pada pembahasan kegiatan penelitian tindakan yang telah dilakukan oleh peneliti, maka dapat dirumuskan beberapa kesimpulan, diantaranya:

1. Strategi pembelajaran dengan menggunakan metode pembelajaran berbasis aktivitas lebih efektif dalam menumbuhkan motivasi belajar siswa Kelas X.AV2 SMKN 1 Wonoasri Kabupaten Madiun pada mata pelajaran Produktif Teknik Audio Video Materi Pembelajaran Arus, Tegangan dan Tahanan Listrik.

2. Strategi pembelajaran dengan menggunakan metode pembelajaran berbasis aktivitas dapat meningkatkan prestasi hasil belajar siswa Kelas X.AV2 SMKN 1 Wonoasri Kabupaten Madiun pada mata pelajaran Produktif Teknik Audio Video Materi Pembelajaran Arus, Tegangan dan Tahanan Listrik.

\section{Saran-saran}

Berdasarkan kesimpulan yang tersebut, maka dapat diberikan saransaran sebagai berikut:

1. Kepada guru Sekolah Menengah Kejuruan agar mempertimbangkan pemberian materi pembelajaran dengan mengenalkan kepada siswa menggunakan berbagai macam strategi. Salah satunya adalah strategi berbasis aktivitas.

2. Strategi pembelajaran berbasis aktivitas bukan satu-satunya strategi yangharus digunakan dalam proses belajar mengajar. Artinya guru perlu mengembangkan strategi belajar dengan teknik lain agar proses belajar siswa lebih variatif. Dengan peningkatan aktivitas siswa dalam kegiatan belajar, maka diharapkan dapat meningkatkan hasil belajar secara optimal.

\section{Daftar Pustaka}

Baharudin, Esa Nur Wahyuni. 2007. Teori belajar dan pembelajaran. Ar-Ruzz Media, Jogjakarta

Djamarah S.B. 2002. Psikologi Belajar. PT Rineka Cipta Jakarta..

Slameto. 2003. Belajar dan Faktor faktor yang mempengaruhinya. PT Rineka Cipta Jakarta.

Hamalik, Oemar. 2002. Perencanaan pengajaran berdasarkan 
pendekatan sistem. PT Bumi Akasara Jakarta

Tu'u, T.S. Th., MM. Pd. 2004. Peran Disiplin pada perilaku dan prestasi siswa. PT Gramedia Widia sarana Jakarta.

Akbar Hawadi, Reni. 2004. Akselerasi. PT Grasindo Anggota Ikapi Jakarta.

Yunanto, Sri Joko. 2004. Sumber Belajar Anak Cerdas. PT Grasindo Anggota Ikapi Jakarta.

Wiyono, Bambang Budi. 2008. Penelitian Tindakan Kelas dan Penulisan Karya Ilmiah. Penerbit Universitas Negeri Malang.

Hadi, S MA. 2001. Statistik Jilid 1. Penerbit ANDI Yogyakarta. 